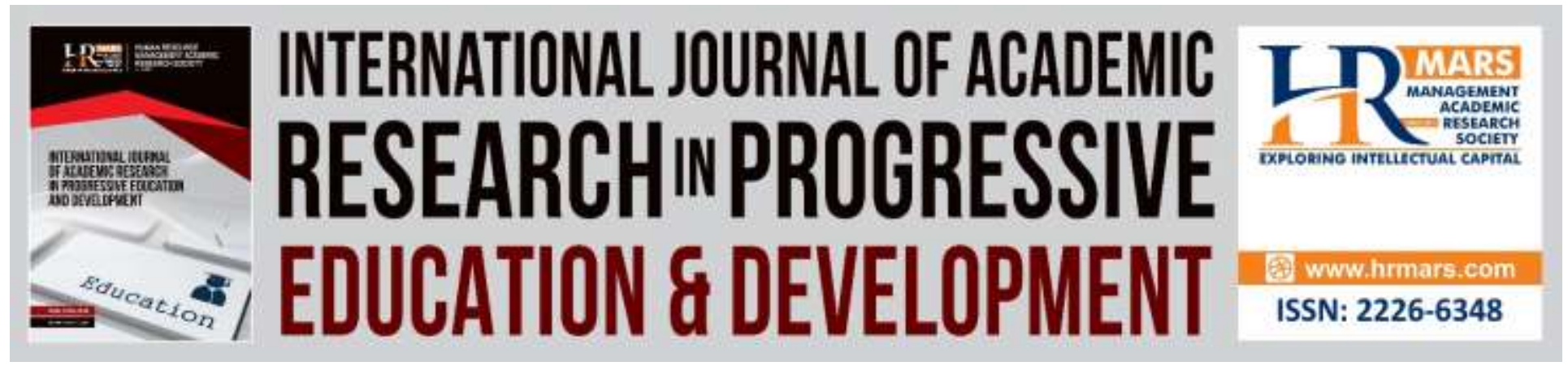

\title{
Study Alkali Metals and Halogens through Learning Stations
}

\section{Wong Choy Wan}

To Link this Article: http://dx.doi.org/10.6007/IJARPED/v8-i3/6425

DOI: $10.6007 /$ IJARPED/v8-i3/6425

Received: 09 Aug 2019, Revised: 28 Aug 2019, Accepted: 02 Sep 2019

Published Online: 25 Sep 2019

In-Text Citation: (Wan, 2019)

To Cite this Article: Wan, W. C. (2019). Study Alkali Metals and Halogens through Learning Stations. International Journal of Academic Research in Progressive Education and Development, 8(3), 316-324.

Copyright: (C) 2019 The Author(s)

Published by Human Resource Management Academic Research Society (www.hrmars.com)

This article is published under the Creative Commons Attribution (CC BY 4.0) license. Anyone may reproduce, distribute, translate and create derivative works of this article (for both commercial and non-commercial purposes), subject to full attribution to the original publication and authors. The full terms of this license may be seen

at: http://creativecommons.org/licences/by/4.0/legalcode

\section{Vol. 8(3) 2019, Pg. 316 - 324}

http://hrmars.com/index.php/pages/detail/IJARPED

JOURNAL HOMEPAGE

Full Terms \& Conditions of access and use can be found at http://hrmars.com/index.php/pages/detail/publication-ethics 


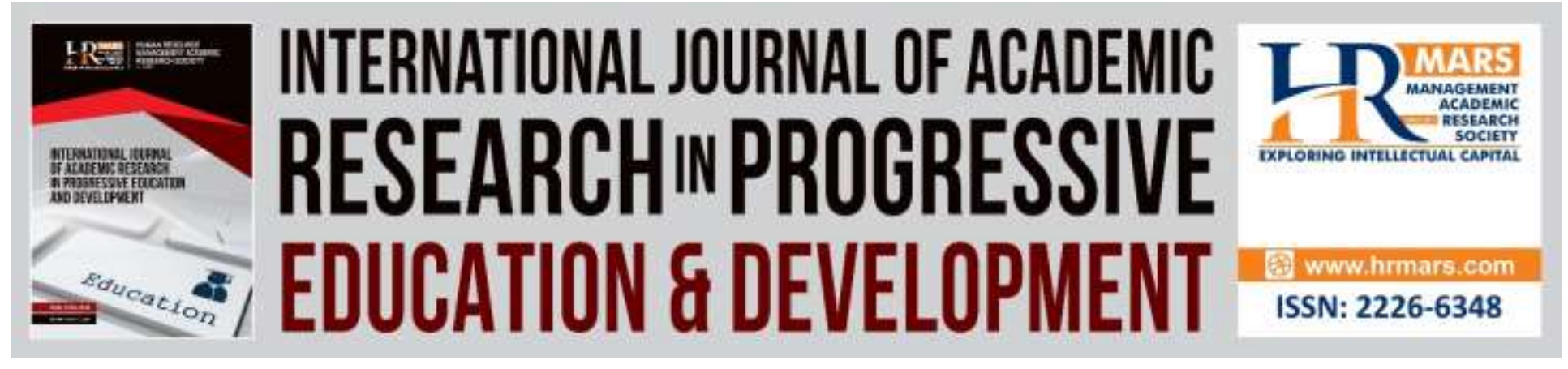

\title{
Study Alkali Metals and Halogens through Learning Stations
}

\author{
Wong Choy Wan \\ SMK Buntong, Ipoh, Perak, Malaysia
}

\begin{abstract}
Periodic Table of Elements is the central to study Chemistry. It is, however considered by students as difficult to learn. Students confused between the change in physical properties when going down the group and chemical properties of Group 1 and Group 17. Students also found that this chapter is not interesting and involve a lot of memorization. The purpose of this research is to enhance students' understanding about alkali metals and halogens through fun learning. 18 Form Four students, aged 16, who study Chemistry involved in this study. Six learning stations that include the physical properties of alkali metals and halogens, chemical properties of alkali metals and halogens, and hands on activities for chemical reactions are used in this study to enhance students' learning. Students are divided randomly into six groups to explore in each leaning station. Formative assessment is carried out after learning activities in each station. Results of assessment shows positive effect of learning stations towards understanding of Periodic Table of Elements, at which $66.67 \%$ of students can master the concepts and hands-on activity about alkali metals while $69.45 \%$ of students understand the chemical properties of halogens. Findings also shows that $88.89 \%$ of students found that the learning stations enable them to understand new concepts easily and made learning alkali metals and halogens interesting and fun. This implies that this teaching and learning method can be used for other topics in chemistry.
\end{abstract}

Keywords: Chemistry, Alkali Metals, Halogens, Learning Stations, Pedagogy

\section{Introduction}

Chemistry is often regarded as a difficult subject (Sirhan, 2007). Abstract nature and words from everyday language with different meaning causes chemistry to be considered by students as a difficult subject (Ozmen, 2007). Periodic Table of Elements is the central to study Chemistry (Mokiwa, 2017). It is, however considered by students as difficult to learn. Students confused between the change in physical properties when going down the group and chemical properties of Group 1 and Group 17. Students also found that this chapter is not interesting and involve a lot of memorization.

Students' interest and achievement in chemistry have declined (Osborne \& Collins, 2000). Teaching and learning method is one of the factors that contribute to the decline in interest and results in Chemistry. Teaching Chemistry through lecturing method is assumed to be an effective 
way to deliver knowledge (Cardellini, 2012). Anyhow students play a passive, non-thinking, information received role (McKeachie, 1994; Madrid, Ahmed, \& Kumar, 2019) in a teachercentred classroom. Chien (2016) stated that how a teacher's teaching pedagogy gives an impact on the interest and confidence of students in learning the subject taught. Hence there is a need to promote learning and understanding Chemistry in a fun way. The purpose of this research is to enhance students' understanding about alkali metals and halogens through fun learning. (Khalid, Pahi, \& Ahmed, 2016)

\section{Learning station}

Learning stations enable all students to engage actively in the learning process. It provides opportunity for students to collaborate among each other to complete a task given at each station. Students explore new concepts and develop idea while completing the task given. Learning stations allow students to work at their own pace. There is no time frame for each station. Students have sufficient time to explore the content given and build their understanding according to their abilities. In other words, through the learning stations, a teacher can identify slow learners and fast learners in the class.

\section{Methodology}

This is a study that involved 18 Form Four students, aged 16, who study Chemistry from an urban school in Ipoh, Perak. The respondents for this study consist of 7 males and 11 females. Convenience sampling is applied in this study. The students are divided randomly into six groups (three in a group). Students moved in their group from one learning station to another to explore and construct idea about alkali metals and halogens.

Six learning stations are set-up for the purpose of this study. At each station, students are required to complete a learning task in group. Stimulus and information are provided in the form of text, video clips, puzzle or hands-on activity to enable students to explore and collaborate about concepts and idea on alkali metals and halogens. Table 1 shows the title, leaning tasks, stimulus and information for each learning station. 
INTERNATIONAL JOURNAL OF ACADEMIC RESEARCH IN PROGRESSIVE EDUCATION AND DEVELOPMENT

Vol. 8, No. 3, 2019, E-ISSN: 2226-6348 @ 2019 HRMARS

Table 1. Leaning tasks, stimulus and information for each learning station

\begin{tabular}{|c|c|c|c|}
\hline Station & Title & Learning task & $\begin{array}{l}\text { Stimulus/ } \\
\text { Information }\end{array}$ \\
\hline 1 & $\begin{array}{l}\text { Physical Properties of } \\
\text { Alkali Metals }\end{array}$ & Drawing of electron arrangement & Table \\
\hline 2 & $\begin{array}{l}\text { Chemical Properties of } \\
\text { Alkali Metals }\end{array}$ & Writing chemical equations & Video clips \\
\hline 3 & $\begin{array}{l}\text { Hands-on- Sodium and } \\
\text { Oxygen Gas }\end{array}$ & Hands-on activity & Tarsia puzzle \\
\hline 4 & $\begin{array}{l}\text { Physical Properties of } \\
\text { Halogens }\end{array}$ & Mind map & Text \\
\hline 5 & $\begin{array}{l}\text { Chemical Properties of } \\
\text { Halogens }\end{array}$ & $\begin{array}{l}\text { Writing chemical equations and } \\
\text { explaining the change in reactivity } \\
\text { of halogens when going down } \\
\text { Group } 17\end{array}$ & $\begin{array}{l}\text { Text and flow } \\
\text { chart }\end{array}$ \\
\hline 6 & Hands-on-Halogen & Hands-on activity & $\begin{array}{l}\text { Procedure for } \\
\text { hands-on activity }\end{array}$ \\
\hline
\end{tabular}

Upon completion of the task given in each station, students are required to complete a formative assessment through Google Form. Table 2 shows an example of assessment for Station 2: Chemical properties of alkali metals.

Table 2. Formative Assessment for Station 2

\begin{tabular}{ll}
\hline Question & Learning task \\
\hline 1 & $\begin{array}{l}\text { From the video clips that you have watched, arrange } \mathrm{Li}, \mathrm{Na} \text { and } \mathrm{K} \text { in } \\
\text { ascending order of reactivity (less reactive } \rightarrow \text { more reactive) }\end{array}$ \\
\hline 2 & $\begin{array}{l}\text { Write a balanced chemical equation for the reaction between sodium and } \\
\text { water. }\end{array}$ \\
\hline 3 & $\begin{array}{l}\text { Write a balanced chemical equation for the reaction between sodium and } \\
\text { oxygen gas. }\end{array}$ \\
& $\begin{array}{l}\text { Write a balanced chemical equation for the reaction between sodium and } \\
\text { chlorine gas. }\end{array}$ \\
\hline
\end{tabular}

\section{Duration}

Once a group of students has completed their learning task and assessment, they moved to the next station that is not occupied with any respondents. There is no fixed duration for each learning station. Students completed their task according to their learning pace. 
Vol. 8, No. 3, 2019, E-ISSN: 2226-6348 @ 2019 HRMARS

After completing six learning stations, students are given a questionnaire on the perception of learning stations to fill up individually. The total duration to complete the task, formative assessment and questionnaire is 120 minutes.

\section{Findings}

The findings of this study are presented according to understanding about alkali metals, understanding about halogens and response in questionnaire on the perception of learning stations.

\section{Understanding about Alkali Metals}

Table 3. Results of Formative Assessment for Alkali Metals

\begin{tabular}{llll}
\hline \multirow{3}{*}{$\begin{array}{l}\text { Station } \\
1\end{array}$} & Question & $\begin{array}{l}\text { Percentage of correct answer } \\
(\%)\end{array}$ & Mean score (\%) \\
\hline & 2 & 83.33 & \\
& 2 & 100 & 94.44 \\
& 3 & 100 & \\
2 & 1 & 50 & 66.67 \\
& 2 & 83.33 & \\
& 3 & 83.33 & \\
& 4 & 50 & \\
& 1 & 83.33 & \\
& 2 & 66.67 & \\
& 3 & 50 & \\
& 4 & 100 & \\
& 5 & 33.33 & \\
\end{tabular}

Table 3 shows the results of formative assessment for learning stations about alkali metals. Results shows that for station 1 , the mean score is high, which is $94.44 \%$ while for station 2 and 3 , the mean score is $66.67 \%$ respectively. 
INTERNATIONAL JOURNAL OF ACADEMIC RESEARCH IN PROGRESSIVE EDUCATION AND DEVELOPMENT

Vol. 8, No. 3, 2019, E-ISSN: 2226-6348 @ 2019 HRMARS

\section{Understanding about Halogens}

Table 4. Results of Formative Assessment for Halogens

\begin{tabular}{|c|c|c|c|}
\hline Station & Question & $\begin{array}{l}\text { Percentage of correct answer } \\
(\%)\end{array}$ & Mean score (\%) \\
\hline \multirow{3}{*}{4} & \multirow{3}{*}{$\begin{array}{l}\text { Mind } \\
\text { map }\end{array}$} & Comprehensive (33.33) & \multirow{3}{*}{-} \\
\hline & & Moderate (16.67) & \\
\hline & & Simple $3(50.00)$ & \\
\hline \multirow{6}{*}{5} & 1 & 66.67 & \multirow{6}{*}{69.45} \\
\hline & 2 & 50.00 & \\
\hline & 3 & 100.00 & \\
\hline & 4 & 66.67 & \\
\hline & 5 & 50.00 & \\
\hline & 6 & 83.33 & \\
\hline \multirow{3}{*}{6} & 1 & 33.33 & \multirow{3}{*}{16.67} \\
\hline & 2 & 16.67 & \\
\hline & 3 & 0.00 & \\
\hline
\end{tabular}

Table 4 shows the results of formative assessment for learning stations about halogens. Results shows that for station $4,33.33 \%$ of students can prepare a comprehensive mind map, $16.67 \%$ prepare a moderate mind map and $50.00 \%$ can only prepare a simple mind map. The mean score for station 5 is $69.45 \%$. Students obtain a low mean score for station 6 , which is $16.67 \%$. 
INTERNATIONAL JOURNAL OF ACADEMIC RESEARCH IN PROGRESSIVE EDUCATION AND DEVELOPMENT

Vol. 8, No. 3, 2019, E-ISSN: 2226-6348 @ 2019 HRMARS

\section{Questionnaire on the Perception of Learning Stations}

Table 5. Results of Perception of Learning Stations

\begin{tabular}{lll}
\hline Question & & \multicolumn{2}{l}{$\begin{array}{l}\text { Percenta } \\
\text { ge(\%) }\end{array}$} \\
\hline How do you find the activity that you have just carried out for the & $\begin{array}{l}\text { Easy } \\
\text { understand }\end{array}$ & 88.89 \\
understanding of new concept? & Difficult & 11.11 \\
\hline & 1 & 27.78 \\
Which station do you like most? & 2 & 0.00 \\
& 3 & 22.22 \\
& 4 & 0.00 \\
& 5 & 0.00 \\
Which station do you don't like most? & 6 & 50.00 \\
\hline & 1 & 0.00 \\
& 2 & 16.67 \\
How would you rate this learning activities? & 3 & 5.56 \\
& 4 & 55.56 \\
& 5 & 11.11 \\
& & 11.11 \\
\hline
\end{tabular}

Table 5 shows the results of students' perception of learning stations. $88.89 \%$ of students found that learning stations enable them to understand new concepts easily. These students also found that this learning activity is interesting. The station that students like most is station 6 (50.00\%), followed by Station 1 (27.78\%) and Station 3 (22.22\%). 55.56\% of students do not like Station 4 while all students like station 1.

\section{Discussion and Conclusion}

For alkali metals, students who can master the chemical properties can also carry out hands on activity successfully. For halogens, results show that students who can answer questions about chemical properties of halogens could not answer questions about science process skills correctly, especially in stating all the variables in the hands-on activity. Students obtained the highest mean score in station 1 . The learning task in this station is the easiest amongst all. Students applied their prior knowledge in drawing electron arrangement to determine the change of atomic size from lithium to potassium. Sirhan (2007) stated that one of the problem areas in Chemistry is chemical formulae and equations. From the results obtained, it was found that $50.00 \%$ of students could not write a balanced a chemical equation. Writing wrong chemical formula of reactant or product is the main cause for this. This shows that 
students have not master the writing of chemical formulae. Remedial practice should be given to enhance the skill of writing chemical formulae.

The study aimed to promote fun learning in Chemistry for the topic alkali metals and halogens through learning station. Results show that students found that learning stations promoted fun learning and enable them to understand the topics easily through learning stations. Through the findings of this study, students preferred the learning stations that involved hands-on activities (Station 3 and Station 6). Most students like Station 6 that requires students to carry out two hands-on activities about chemical properties of halogens, even though they could not answer the assessment question well. This implies that hands-on activities will attract students' interest and attention to learn and understand new concept. Results show that students dislike drawing mind map after reading a given passage. Students do not have reading habit and found that transforming important points into mind map boring and difficult.

Learning stations do not merely promote fun learning in chemistry, especially in studying alkali metals and halogens, it also reveals students' strengths and weaknesses of their prior knowledge. Facilitating students' learning through learning stations provide opportunity for students to explore and construct idea about a new topic. Learning station is one of the $21^{\text {st }}$ century teaching and learning strategy that enable students to learn in a student-centred classroom. Learning stations provides sufficient time for students to engage and explore learning task given to them at their own pace. Feedback from formative assessment inform teacher and students about their strengths and weaknesses. Reinforcement and remedial sessions can be planned and arranged for students' improvement in a certain topic or subtopic. Learning stations can be applied in teaching other chemistry topics, such as chemical bonding and electrochemistry, indeed, it might be used in the teaching of other subjects.

\section{Corresponding Author}

Wong Choy Wan, SMK Buntong, Ipoh, Perak, Malaysia, Email: wongchoywan.wcw@gmail.com, SMK Buntong, 30100 Ipoh, Perak, Malaysia.

\section{References}

Cardellini, L. (2012). Chemistry: Why the Subject is Difficult? Educacion Quimica, 23(2), 305-310. DOI: https:// doi.org/10.1016/50187-893X(17)30158-1

Chien, L. S. (2016). Form Four Chemistry Teachers' Conceptualization of Pedagogical Content Knowledge, (Unpublished doctoral dissertation). University of Malaya, Malaysia.

Khalid, N., Pahi, M. H., \& Ahmed, U. (2016). Loosing your best talent: Can leadership retain employees? The dilemma of the banking sector of Hyderabad Sindh, Pakistan: A mediation investigation. International Review of Management and Marketing, 6(3), 608616.

Madrid, D., Ahmed, U., \& Kumar, R. (2019). Examining the Impact of Classroom Environment on Entrepreneurship Education: Case of a Private University in Bahrain. Journal of Entrepreneurship Education, 22(1), 1-8.

McKeachie, W. J. (1994). Teaching Tips. Strategies, Research, and Theory for College and University Teachers ( $9^{\text {th }}$ ed). D.C. Health and Co., Lexington, MA. 
Mokiwa, H. O. (2017). Reflections on Teaching Periodic Table Concepts: A Case Study of Selected Schools in South Africa. Eurasia Journal of Mathematics, Science and Technology Education, 13(6), 1563-1573. DOI: https://doi.org/10.12973/Eurasia.2017.00685a

Osborne, J. F. \& Collins, S. (2000). Pupils' and Parents' Views of the School Science Curriculum. King's College London, London.

Ozmen, H. (2007). Some Students Difficulties in Chemistry: A literature view of chemical bonding. Journal of Chemical Education and Technology, 13(2), 147-159.

Sirhan, G. (2007). Learning Difficulties in Chemistry: An Overview. Journal of Turkish Science Education, 4(2), 2-20. 